\title{
Board Composition Nexus to Financial Performance of Listed Companies on PSX: An Empirical Analysis
}

\author{
Muhammad Uzair Farooq Khan*, Fayyaz Ali Khan, Luguang Zhang \\ School of Accounting, Zhejiang Gongshang University, Hangzhou, China \\ Email: *mufkhan@outlook.com
}

How to cite this paper: Khan, M.U.F., Khan, F.A. and Zhang, L.G. (2019) Board Composition Nexus to Financial Performance of Listed Companies on PSX: An Empirical Analysis. American Journal of Industrial and Business Management, 9, 2190-2201.

https://doi.org/10.4236/ajibm.2019.912145

Received: November 8, 2019

Accepted: December 16, 2019

Published: December 19, 2019

Copyright $\odot 2019$ by author(s) and Scientific Research Publishing Inc. This work is licensed under the Creative Commons Attribution International License (CC BY 4.0).

http://creativecommons.org/licenses/by/4.0/

\begin{abstract}
This paper evaluated the nexus of board composition with the financial performance of the firms listed on PSX. The research specifically considered the case of KSE-30 index and data spanned from 2014 to 2018 which asserts 5 years. The board composition was represented by board size, gender diversity, non-executive directors (NEDs), and board independence controlled by age of firms, financial leverage and firm size. For financial performance, the metrics of ROE and ROA was utilised. The analysis techniques incorporate regression and correlation. In accordance with regression, the influence on NEDs was positive on both ROA and ROE in a significant manner whereas, gender diversity affected them negatively. Besides, board size negatively and board independence positively influenced financial performance but partially. In addition, financial leverage positively and partially controlled the nexus.
\end{abstract}

\section{Keywords}

Board Composition, Financial Performance, PSX, KSE-30 Index

\section{Introduction}

Fundamentally, the composition of the board of different corporations contributes significantly to the governance practices, strategic decision-making process and accomplishment of its aims [1] [2]. Therefore, the concept of corporate governance is deemed as a structure through which the organisations are managed and controlled [3]. However, the concept emerged after the decline of WorldCom and Enron in US and East-Asian financial crisis along with the downfall of several companies across the globe [4]. The corporations felt the need to substantiate the mechanisms of the companies by enriching them with effective rules and policies. Since then, authors, academicians and practitioners 
have tested the association of CG and board composition which can be regarded as a part of CG with the profitability and firms' performance [5] [6].

In the context of board composition, academicians and scholars have formed frameworks related to CG to stabilise the companies' performance and financial markets as a whole, for instance; [7] referred to board size, its independence and leadership structure as board's composition. The stabilisation of the CG mechanisms is dependent on its board and its effectiveness in terms of control and decision-making draw the attention of potential investors towards the organisation, aid in meeting legal requirements, and assist in living up to the expectations of the stakeholders [8].

Considering the relevancy of the subject, the focus and aim of this paper are to evaluate the nexus of board composition with the firms' performance where the case of firms operating in Pakistan and registered in PSX. The foundation of Pakistan Stock Exchange (PSX) was laid in September 1947 and was named as Karachi Stock Exchange (KSE), however, in January 2016, the other two exchanges of the country along with KSE were integrated under the Government Act 2012 [9]. However, this research is sanctioned to the empirical analysis of KSE-30 index which has been updated by PSX as of June 2018. The study carried out by [10] and [11] also underpinned the case of KSE-30 index in a similar context by referring to the significance of their high market capitalisation and need for further research considering the business dynamics of Pakistan. Concerning the aim mentioned earlier, the objectives to be covered in this paper are as follows:

- To evaluate the nexus of board composition with the financial performance of the companies registered in KSE-30 index.

- To contribute the propositions for improving the board composition of the companies listed in KSE-30 index.

\section{Literature Review}

While a set of different factors contribute towards the efficiency and performance of organisations, it is imperative to understand how board composition plays its role in finance performance of firms. It has been understood that work complexities and intricacies have been augmenting over the years and it has become challenging for businesses to ensure high financial performance. With a set of internal and external factors impacting the organisations, it may get daunting for companies to maintain operational efficiency in the long run [12]. In this regard, it is critical to understand the role and importance of different stakeholders and their contribution towards financial performance so that they can be better controlled and managed to attain the desired objectives. Along with different aspects and elements playing their role in financial performance, board composition has been identified to be one of the most significant factors.

Understanding that board of directors are the supreme authority in terms of organisational control and management, it is necessary for a firm to understanding its related dynamics and role to be able to adequately assess how it contributes towards the financial performance. The board of the firm not only 
has to be effective and efficient but it also must take into consideration different aspects such as board size, board independence, gender diversity and non-executive directors [13]. In assessing how well the board is performing and how it is contributing towards performance of the company, a set of different aspects could be evaluated with regards to its establishment. Board size for instance may be one significant element that could have an effect on the financial performance on the whole. Realising that the nature of every company is different from the other along with its operational capacity and overall size, the board size also may be different in the same manner. Having a board size that is broader or lesser than the required amount may lead the company towards inefficient management and poor financial outcomes [14].

Board independence could further be realised as another contributing factor in terms of organisational performance and efficiency. In certain cases, the board is given full authority and independence in which the decisions are taken in accordance and business functionality is carried out. While in other cases, the board is not kept fully independent and there are certain limitations kept on it in terms of decision-making and policy regulations. While either case could be effective, what matters the most in the nature and type of the organisation [15]. Also, another dependent factor for this decision is the ability and capacity of the board according to which it is either kept fully independent or not. Further, gender diversity has also been considered to be a critical aspect in overall board composition. It could be understood that the nature of work of every business may be different from the other and while a certain gender may be efficient in sort of business types, it may not be equally efficient in the other. In other words, while males could be considered having an effective performance and suitability in manufacturing industries, they may not be equally useful in a healthcare industry [13] [14] [16].

The composition of the board is considered to be highly critical for any organisation's success and performance. The way a board is established and the related dynamics of it significantly contributes and depicts how a firm is going to be performing financially. The efficiency and effectiveness of the board could be portrayed in how well a business is doing and for this matter it needs to be made sure that the composition is made in consideration to the nature and type of the business [17] [18]. Moreover, the age and size of the company have also been considered to be potential elements that may have their contributing role in the overall financial performance of the business. The time since when the company is established may depict and control the impact of board composition on financial performance. The related elements could be considered to be the experience that comes with it, market knowledge, exposure, potential and more. Lastly, financial leverage could also be understood as a highly vital aspect related to board composition and firm's financial performance. While the efficiency and effectiveness of the board significantly matters in how well it will perform, the financial leverage and structure also contributes and impacts the outcomes associated with it [19]. Considering the variables discussed, the proposed conceptual model of the study has been presented by Figure 1 . 


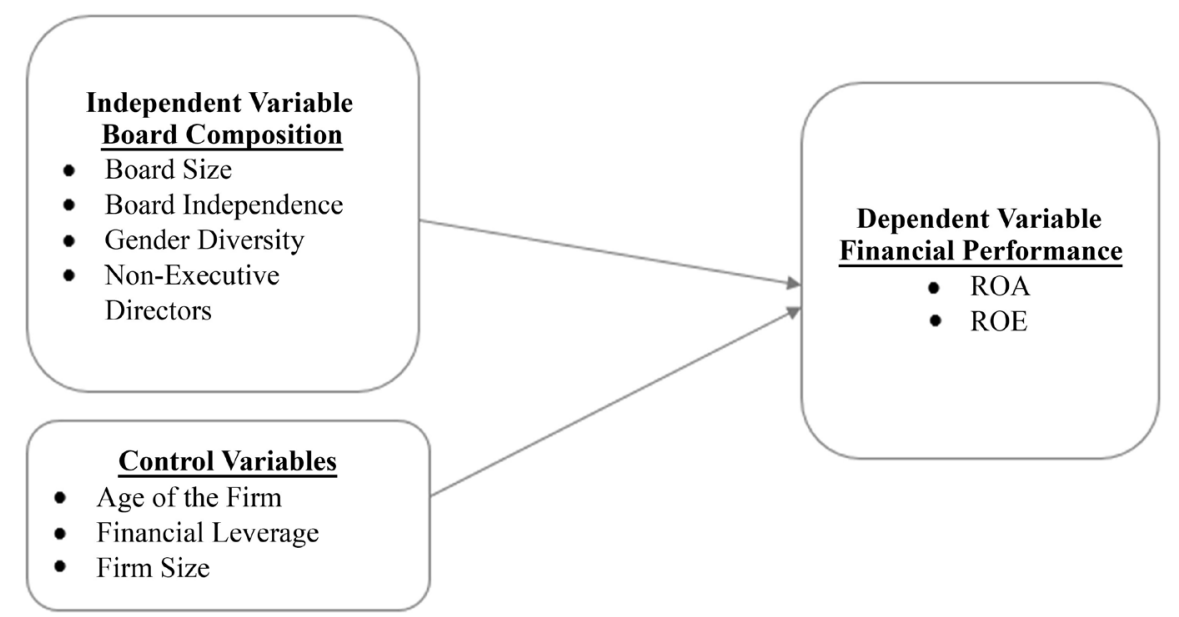

Figure 1. Conceptual model of the study.

Source:

In accordance with the variables of the study and reviewed literature, following hypotheses have been formed:

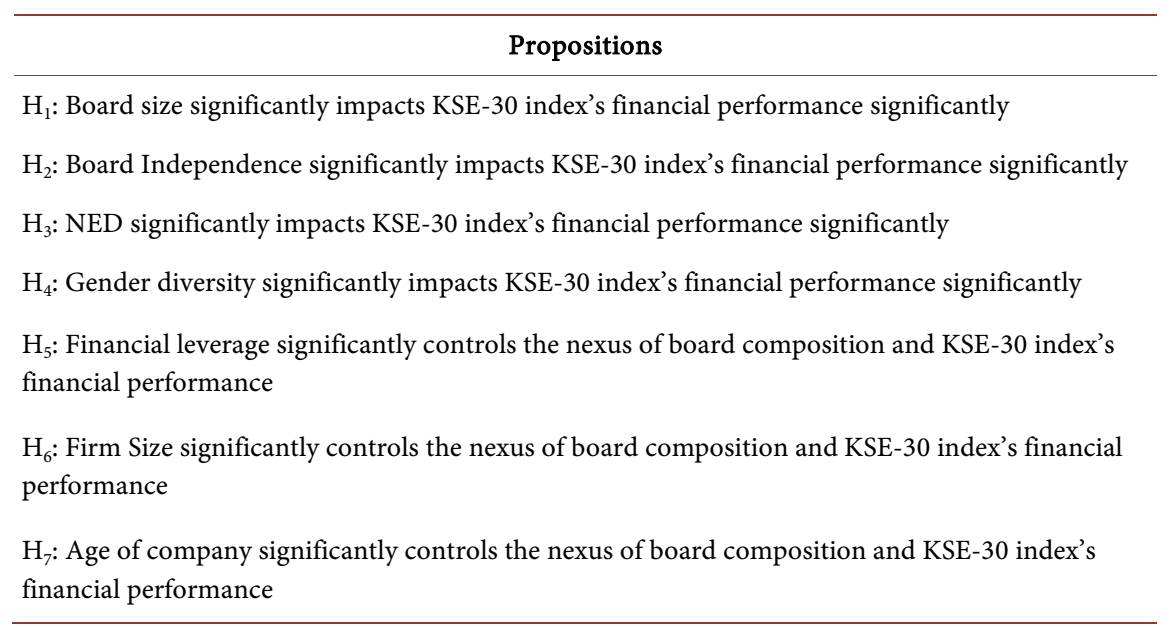

\section{Methodology}

\subsection{Data and Sample}

The following research has utilised secondary data obtained from authentic sources like Thomson Reuters, Business Recorder and PSX's website. Firstly, the companies listed in KSE-30 index were chosen as updated by PSX as of June 2018. Therefore, the total sample of the study comprises of 30 companies in total belonging to different sectors like, cement, financial, chemical, oil and gas, petroleum and others. In this case, the employed sampling is purposive that is a non-probability technique [20]. They have been chosen because on PSX, they are top performing companies and are listed in KSE-30 index. However, the years considered are 5 spanning from 2014 to 2018 . The underlying reason of choosing 5 years is the limited availability of the data of Pakistani companies on authentic sources. In addition, other than databases, the variables representing the 
board composition have been accumulated from the annual reports of the respective companies.

\subsection{Variables and Measurement}

The variables and measurement of the variables underpinned in this study have been presented in Table 1. However, other that dependent and independent variable, this research has also used some control variables, for instance; firms' size and its age.

\subsection{Data Analysis Technique}

The analysis technique includes descriptive statistics, correlation analysis and panel least squares regression. The technique is also supported by various researches, for instance; [10] and [12]. In addition, since the data is panel in nature, fixed and random effects testing has been done on Stata. The most appropriate model has been chosen on the basis of Hausman testing.

\subsection{Empirical Model}

The empirical model has been constructed using the variables discussed and has been presented as follows:

$$
\overparen{\mathrm{Per}_{i t}}=\alpha_{1}+\beta_{1} \mathrm{BS}_{i t}+\beta_{2} \mathrm{BID}_{i t}+\beta_{3} \mathrm{GD}_{i t}+\beta_{4} \mathrm{ND}_{i t}+\beta_{5} \mathrm{FRS}_{i t}+\beta_{6} \mathrm{Age}_{i t}+\beta_{7} \mathrm{FL}_{i t}+\epsilon_{i t}
$$

In the equation above, "Per" is representing the performance measured using "ROA" and "ROE" as dependent variables. "BS" is the size of the board, "BID" is the board independence, "GD" is the gender diversity, "ND" is the non-executive directors, "FRS" is the firm size, and "FL" is the financial leverage. The betas are representing regression coefficients of the respective variables of the study. In addition, " $i$ " is representing companies, " $\vec{l}$ " is the time-period and $\epsilon$ is the error of the model.

Table 1. Variables of the study.

\begin{tabular}{|c|c|c|}
\hline Variables & Measurement & Reference \\
\hline \multicolumn{3}{|c|}{ Dependent Variables } \\
\hline $\mathrm{ROA}$ & Net income/Total assets & $[11]][13][16][18]$ \\
\hline ROE & Net income/Shareholders' equity & $[11]][13][16][18]$ \\
\hline \multicolumn{3}{|c|}{ Independent Variables } \\
\hline Board Size & Number of members on board & {$[4][12][16]$} \\
\hline Board Independence & $\%$ of independent directors & {$[4][12][16][19]$} \\
\hline Gender Diversity & $\%$ of females on board & {$[4][14][17][18]$} \\
\hline Non-Executive Directors & $\%$ of non-executive directors & {$[14][15][21][26]$} \\
\hline \multicolumn{3}{|c|}{ Control Variables } \\
\hline Firm Size & Log of total assets owned by companies & {$[4][12][14]$} \\
\hline Age of the Firm & No. of operational years & {$[14][15][16]$} \\
\hline Financial Leverage & Debt/Equity & {$[13]$} \\
\hline
\end{tabular}




\section{Results and Analysis}

This section of the paper is dedicated to the demonstration of the results and the analysis pertaining to it. Firstly, descriptive statistics have been computed of companies listed in KSE-30 index. The descriptive statistics is followed by the computation of correlation and then panel least squared regression. In addition, Hausman testing is also conducted for model selection.

\subsection{Descriptive Statistics}

Descriptive statistics include mean as a central tendency metric, standard deviation as dispersion measure, minimum and maximum value. The average ROA is computed to be $9 \%$ over the span of 5 years ranging from 2014 to 2018 with even higher deviation of $10 \%$. Besides, another performance metric which is ROE and its average is computed to be $20 \%$ with deviation of $21 \%$. In the case of ROE, the minimum is quite lower which was of SNGP in 2015. Given this, the average firm size is computed to have a mean value of 11.10 which means that on average the total assets possess by companies in KSE-30 index is in billions. The debt to equity ratio on average is computed to be 0.81 . The mean of board size is 10 members, board independence is $27 \%$, non-executive directors are $53 \%$, gender diversity is $3 \%$ and company's age is 45 years on average. Table 2 is depicting the results.

\subsection{Analysing Nexus of Board Composition with the Financial Performance Using Correlation Analysis}

The financial performance of the companies is said to be linked with the composition of board, however, with respect to the industries, the dynamism differ [21] [22]. The linear association of one variable tested using correlation with another variable [23]. Therefore, the correlation of independent and control variables that are financial leverage, firm size, firms' age, board independence, NEDs, gender diversity, and board size have been tested with ROA and ROE. The association of financial leverage with both ROA and ROE is negative and

Table 2. Descriptive statistics.

\begin{tabular}{cccccc}
\hline Variable & Obs & Mean & Std. Deviation & Min & Max \\
\hline ROA & 150 & $9 \%$ & $10 \%$ & $-4 \%$ & $68 \%$ \\
ROE & 150 & $20 \%$ & $21 \%$ & $-70 \%$ & $94 \%$ \\
Financial Leverage & 150 & 0.81 & 1.40 & 0.00 & 10.23 \\
Firm Size & 150 & 11.10 & 0.69 & 9.52 & 12.46 \\
Board Size & 150 & 10 & 3 & 6 & 23 \\
Board Independence & 150 & $27 \%$ & $19 \%$ & $0 \%$ & $93 \%$ \\
Non-Executive Directors (NED) & 150 & $53 \%$ & $23 \%$ & $0 \%$ & $93 \%$ \\
Gender Diversity & 150 & $3 \%$ & $6 \%$ & $0 \%$ & $25 \%$ \\
Age of Company & 150 & 44.97 & 19.65 & 7.00 & 77.00 \\
\hline
\end{tabular}


weak as the computed values are -0.21 and -0.15 . The relationship of firms' size is computed to be negative and weak and similar is the case of boards' size with both ROA and ROE. In addition, the association of boards' independence is computed to be negligibly weak and negative with ROE and ROA. The nexus of NEDs with the financial performance is also computed to be weak. In addition, the association of gender diversity is weak and positive with ROA but with ROE, no association is found. Lastly, the age of companies is found to be negligibly associated with the ROA in a positive manner and ROE in a negative manner. Table 3 is depicting the results.

\subsection{Analysing Effect of Board Composition on KSE-30 Index Companies' Financial Performance Using Regression Analysis}

\subsubsection{Analysing Effect on ROA}

When the panel character is recognised in the data then panel least squares regression is employed on the data [24]. The chosen model is fixed effects on the basis of Hausman's test present in Table 4 because, the null hypothesis assumes random model which is rejected [25]. The overall model in accordance with f-statistic is computed to be significant because at $\mathrm{f}=3.75$, the $\mathrm{p}$-value is computed to be 0.001 ( $p$-value $<0.05$ ). In addition, the variance in financial leverage, board size, gender diversity, age of company, NEDs, firm size, and board independence is explaining $18.87 \%$ variance in ROA of KSE-30 index companies. In terms of individual significance, board independence, NED and gender diversity are computed to be statistically significant having p-values $0.04,0.02$ and 0.00 respectively which are lower than $5 \%$. Given this, board independence and NEDs are found to have positive effect on firms' return. This implies more independent firm having more NEDs but lesser females would be profitable. The results are presented in Table 5 .

\subsubsection{Analysing Effect on ROE}

The effect on ROE is further tested of the same independent and independent variables whose results are presented in Table 6 . In the case of ROE, the chosen

Table 3. Correlation analysis.

\begin{tabular}{|c|c|c|c|c|c|c|c|c|c|}
\hline & ROA & ROE & $\begin{array}{l}\text { Financial } \\
\text { Leverage }\end{array}$ & Firm Size & Board Size & $\begin{array}{c}\text { Board } \\
\text { Independence }\end{array}$ & $\begin{array}{l}\text { Non-Executive } \\
\text { Directors }\end{array}$ & $\begin{array}{l}\text { Gender } \\
\text { Diversity }\end{array}$ & $\begin{array}{c}\text { Age of } \\
\text { Company }\end{array}$ \\
\hline ROA & 1 & & & & & & & & \\
\hline ROE & 0.55 & 1 & & & & & & & \\
\hline Financial Leverage & -0.21 & -0.15 & 1 & & & & & & \\
\hline Firm Size & -0.36 & -0.21 & 0.10 & 1 & & & & & \\
\hline Board Size & -0.16 & -0.01 & 0.43 & 0.04 & 1 & & & & \\
\hline Board Independence & -0.05 & -0.10 & 0.09 & 0.27 & 0.14 & 1 & & & \\
\hline Non-Executive Directors & -0.11 & -0.04 & 0.22 & -0.04 & 0.22 & -0.30 & 1 & & \\
\hline Gender Diversity & 0.10 & 0.00 & -0.04 & -0.05 & 0.00 & -0.04 & 0.10 & 1 & \\
\hline Age of Company & 0.06 & -0.02 & -0.04 & 0.33 & -0.11 & 0.16 & -0.01 & -0.09 & 1 \\
\hline
\end{tabular}


Table 4. Hausman testing.

\begin{tabular}{cc}
\hline Chi-Squared Statistics & 28.39 \\
Probability Value & 0.0002 \\
\hline
\end{tabular}

Table 5. Analysing nexus of board composition with ROA.

\begin{tabular}{ccccc}
\hline Variable & Coefficient & Std. Error & t-statistics & p-value \\
\hline Financial Leverage & -0.02 & 0.01 & -1.57 & 0.12 \\
Firm Size & -0.01 & 0.06 & -0.19 & 0.85 \\
Board Size & -0.01 & 0.00 & -1.52 & 0.13 \\
Board Independence & 0.16 & 0.08 & 2.13 & 0.04 \\
Non-Executive Directors (NED) & 0.17 & 0.07 & 2.34 & 0.02 \\
Gender Diversity & -0.91 & 0.21 & -4.28 & 0.00 \\
Age of Company & 0.00 & 0.01 & 0.74 & 0.46 \\
Intercept & 0.02 & 0.51 & 0.04 & 0.97 \\
F(7, 113) & 3.75 & & R-Squared & $18.87 \%$ \\
sig & 0.0011 & & Observations & 150 \\
\hline
\end{tabular}

Table 6. Analysing nexus of board composition with ROE.

\begin{tabular}{ccccc}
\hline Variable & Coefficient & Std. Error & t-statistics & p-value \\
\hline Financial Leverage & 0.065 & 0.029 & 2.280 & 0.024 \\
Firm Size & 0.002 & 0.152 & 0.010 & 0.990 \\
Board Size & -0.025 & 0.012 & -2.180 & 0.031 \\
Board Independence & 0.328 & 0.199 & 1.650 & 0.101 \\
Non-Executive Directors & 0.518 & 0.184 & 2.820 & 0.006 \\
Gender Diversity & -2.034 & 0.547 & -3.720 & 0.000 \\
Age of Company & 0.015 & 0.013 & 1.130 & 0.260 \\
Intercept & -0.597 & 1.306 & -0.460 & 0.649 \\
F(7, 113) & 5.07 & & R-Squared & $24 \%$ \\
Sig-Value & 0.00 & Observations & 150 \\
\hline
\end{tabular}

models are fixed effects model for the same reason explained earlier by [25] on the basis of Hausman's test presented in Table 7. In terms of ROE, the overall model is significant with $\mathrm{f}$-statistics $=5.07$ and sig value $=0.00(\mathrm{p}$-value $<0.05)$. In addition, the variance in financial leverage, board size, gender diversity, age of company, NEDs, firm size, and board independence is explaining $24 \%$ variance in ROE of KSE-30 index companies. Individually, the effect of board size, NEDs, gender diversity is computed to be significant having sig values $0.031,0.006$ and 0.000 (p-values $<0.05$ ). The effect of board size and gender diversity is computed to be negative and NEDs have a positive influence. This infers that companies with lesser members and females on board with more NEDs would be 
more profitable in terms of ROE. In addition, financial leverage significantly controls the nexus of board composition with financial performance positively.

\subsection{Summary of Hypotheses}

The summary of the hypotheses has been given as follows where NED and gender diversity are found to be significant in both models in positive and negative manner respectively. The findings have been presented in a tabular manner in Table 8.

\section{Discussion}

Work complexities and business environment have been becoming increasingly complex for organisations in different sectors and so attaining high financial performance has become daunting for organisations. The composition of board has been identified to be playing a considerably important role in how well organisations perform financially and so all its related components and elements have been understood critically [17]. Board size, board independence, gender diversity and non-executive directors have been considered to be the potential element of board composition that have their impact on financial efficiency of the company. While a set of different external factors impact the performance of organisations, internal factors such as board composition have also been identified to be playing an equally essential role [13] [19]. The fact that this level of management has the ultimate decision making authority its own effectiveness

Table 7. Hausman testing.

$\begin{array}{cc}\text { Chi-Squared Statistics } & 45.31 \\ \text { Sig Value } & 0.000\end{array}$

Table 8. Assessment summary table.

\begin{tabular}{|c|c|}
\hline Propositions & Results \\
\hline $\begin{array}{l}\mathrm{H}_{1} \text { : Board size significantly impacts KSE- } 30 \text { index's financial performance } \\
\text { significantly }\end{array}$ & $\begin{array}{l}\text { Partially significant } \\
\text { negatively (with ROE) }\end{array}$ \\
\hline $\begin{array}{l}\mathrm{H}_{2} \text { : Board Independence significantly impacts KSE-30 index's financial } \\
\text { performance significantly }\end{array}$ & $\begin{array}{l}\text { Partially significant } \\
\text { positively (with ROA) }\end{array}$ \\
\hline $\begin{array}{l}\mathrm{H}_{3} \text { : NED significantly impacts KSE- } 30 \text { index's financial performance } \\
\text { significantly }\end{array}$ & Significant (positive) \\
\hline $\begin{array}{l}\mathrm{H}_{4} \text { : Gender diversity significantly impacts KSE-30 index's financial } \\
\text { performance significantly }\end{array}$ & Significant (negative) \\
\hline $\begin{array}{l}\mathrm{H}_{5} \text { : Financial leverage significantly controls the nexus of board composition } \\
\text { and KSE-30 index's financial performance }\end{array}$ & $\begin{array}{l}\text { Partially significant } \\
\text { positively (with ROE) }\end{array}$ \\
\hline $\begin{array}{l}\mathrm{H}_{6} \text { : Firm Size significantly controls the nexus of board composition and } \\
\text { KSE- } 30 \text { index's financial performance }\end{array}$ & Insignificant \\
\hline $\begin{array}{l}\mathrm{H}_{7} \text { : Age of company significantly controls the nexus of board composition } \\
\text { and KSE-30 index's financial performance }\end{array}$ & Insignificant \\
\hline
\end{tabular}


and potential has to considerably high so that it may cater and resolve the different adversities that keep arising over the operational years. While each of these factors has their own significance and implications, it also depends on the financial leverage of the company in terms of how well the present resources will be utilised to attain the desired goals [21].

\section{Conclusion and Recommendations}

The paper examined the nexus of board composition with the financial performance considering the case of PSX. The analysis was conducted empirically where companies listed in KSE-30 index were considered spanning from 2014 to 2018. The empirical assessment has certain implications as well considering the significance of different variables.

\subsection{Implications and Recommendations}

The results for Pakistani companies irrespective of the industry they are operating in have certain implications. Firstly, the Corporate Governance Code needs to be further reinforced in Pakistan. Secondly, the companies should include more NEDs on board as they have a positive influence on the financial performance. Lastly, the board needs to be more independent with lesser number of members serving the board as implied by the study. Consequently, the regulators of Pakistan should consider the findings and the companies should strategize their policies accordingly.

\subsection{Contribution of the Study}

Firstly, the research has contributed to the body of knowledge related to corporate governance and financial performance. Secondly, it has contributed to putting forward the key variables that are affecting the financial performance of the companies listed in PSX and specifically in KSE-30 index. Thirdly, it has contributed with its findings to devise policies in the companies having large market capitalisation and are listed in KSE-30 to further sustain in the index.

\subsection{Limitations of the Study}

The following research was limited to Pakistan only and KSE-30 index especially. In addition, the sample size is limited to 30 companies spanning from 2014 to 2018. The variables considered in the study were also limited whether in terms of performance, board composition or control variables. Therefore, this study may not be generalised to any other country.

\subsection{Future Research Directions}

Firstly, future researches can consider large sample specifically data of more years. In addition, more variables can be considered in the future for board composition, for instance; nationality of the directors and board members, their ages, CSR committee, audit committee or CEO's duality. Given this, moderating 
or mediating role of political connection can also be tested in the future by the researchers to enhance and extend the findings of this study.

\section{Conflicts of Interest}

The authors declare no conflicts of interest regarding the publication of this paper.

\section{References}

[1] Behl, R. (2018) Business Governance and Society: Analyzing Shifts, Conflicts, and Challenges. Springer, Berlin.

[2] Agyemang, O.S. and Castellini, M. (2015) Corporate Governance in an Emergent Economy: A Case of Ghana. Corporate Governance, 15, 52-84. https://doi.org/10.1108/CG-04-2013-0051

[3] Calder, A. (2008) Corporate Governance: A Practical Guide to the Legal Frameworks and International Codes of Practice. Kogan Page Publishers, London.

[4] Mahmood, Z., Kouser, R., Ali, W., Ahmad, Z. and Salman, T. (2018) Does Corporate Governance Affect Sustainability Disclosure? A Mixed Methods Study. Sustainability, 10, 207. https://doi.org/10.3390/su10010207

[5] Song, S., Van Hoof, H.B. and Park, S. (2017) The Impact of Board Composition on Firm Performance in the Restaurant Industry: A Stewardship Theory Perspective. International Journal of Contemporary Hospitality Management, 29, 2121-2138. https://doi.org/10.1108/IJCHM-05-2016-0283

[6] García Martín, C.J. and Herrero, B. (2018) Boards of Directors: Composition and Effects on the Performance of the Firm. Economic Research Ekonomskaistraživanja, 31, 1015-1041. https://doi.org/10.1080/1331677X.2018.1436454

[7] Maassen, G.F. (1999) An International Comparison of Corporate Governance Models: A Study on the Formal Independence and Convergence of One-Tier and Two-Tier Corporate Boards of Directors in the Unites States of America, the United Kingdom and the Netherlands (No. 31) Gregory Maassen. https://doi.org/10.1111/1467-8683.00126

[8] Chiang, H.T. and Lin, M.C. (2011) Examining Board Composition and Firm Performance. The International Journal of Business and Finance Research, 5, 15-27.

[9] Psx.com.pk (2019) Pakistan Stock Exchange Limited-|Psx| Exchange. https://www.psx.com.pk/psx/exchange/profile/about-us

[10] Yasser, Q.R., Entebang, H.A. and Mansor, S.A. (2011) Corporate Governance and Firm Performance in Pakistan: The Case of Karachi Stock Exchange (KSE)-30. Journal of Economics and International Finance, 3, 482-491.

[11] Sultan, K. (2018) Effects of Corporate Governance on Organization's Performance: Evidence from Karachi Stock Exchange (30 Index). International Journal of Academic Research in Accounting, Finance and Management Sciences, 8, 63-72.

[12] Khan, A., Tanveer, T. and Malik, U. (2017) An Empirical Analysis of Corporate Governance and Firm Value: Evidence from KSE-100 Index. Accounting, 3, 119-130. https://doi.org/10.5267/j.ac.2016.7.003

[13] Atty, A.M.A., Moustafasoliman, M. and Youssef, A.E. (2018) The Effect of Board of Directors Characteristics on Firm's Financial Performance: An Empirical Study on the Most Active Firms in the Egyptian Stock Exchange. Open Access Library Journal, 5, 1-19. https://doi.org/10.4236/oalib.1104993 
[14] Báez, A.B., Báez-García, A.J., Flores-Muñoz, F. and Gutiérrez-Barroso, J. (2018) Gender Diversity, Corporate Governance and Firm Behavior: The Challenge of Emotional Management. European Research on Management and Business Economics, 24, 121-129. https://doi.org/10.1016/j.iedeen.2018.07.001

[15] Gafoor, C.A., Mariappan, V. and Thyagarajan, S. (2018) Board Characteristics and Bank Performance in India. IIMB Management Review, 30, 160-167. https://doi.org/10.1016/j.iimb.2018.01.007

[16] Buallay, A., Hamdan, A. and Zureigat, Q. (2017) Corporate Governance and Firm Performance: Evidence from Saudi Arabia. Australasian Accounting, Business and Finance Journal, 11, 78-98. https://doi.org/10.14453/aabfj.v11i1.6

[17] Ionascu, M., Ionascu, I., Sacarin, M. and Minu, M. (2018) Women on Boards and Financial Performance: Evidence from a European Emerging Market. Sustainability, 10, 1644. https://doi.org/10.3390/su10051644

[18] Muravyev, A., Talavera, O. and Weir, C. (2016) Performance Effects of Appointing Other Firms' Executive Directors to Corporate Boards: An Analysis of UK Firms. Review of Quantitative Finance and Accounting, 46, 25-45. https://doi.org/10.1007/s11156-014-0460-6

[19] Abidin, Z.Z., Kamal, N.M. and Jusoff, K. (2009) Board Structure and Corporate Performance in Malaysia. International Journal of Economics and Finance, 1, 150-164. https://doi.org/10.5539/ijef.v1n1p150

[20] Etikan, I., Musa, S.A. and Alkassim, R.S. (2016) Comparison of Convenience Sampling and Purposive Sampling. American Journal of Theoretical and Applied Statistics, 5, 1-4. https://doi.org/10.11648/j.ajtas.20160501.11

[21] Yasser, Q.R. (2012) Effects of Female Directors on Firms Performance in Pakistan. Modern Economy, 3, 817-825. https://doi.org/10.4236/me.2012.37104

[22] Yameen, M., Farhan, N.H. and Tabash, M.I. (2019) The Impact of Corporate Governance Practices on Firm's Performance: An Empirical Evidence from Indian Tourism Sector. Journal of International Studies, 12, 208-228. https://doi.org/10.14254/2071-8330.2019/12-1/14

[23] Moutinho, L. and Hutcheson, G.D. (2011) The SAGE Dictionary of Quantitative Management Research. Sage Publications, Thousand Oaks. https://doi.org/10.4135/9781446251119

[24] Croissant, Y. and Millo, G. (2008) Panel Data Econometrics in R: The plm Package. Journal of Statistical Software, 27, 1-43. https://doi.org/10.18637/jss.v027.i02

[25] Wooldridge, J.M. (2016) Introductory Econometrics: A Modern Approach. Nelson Education, Toronto.

[26] Roy, A. (2014) Corporate Governance and Firm Performance: An Exploratory Analysis of Indian Listed Companies. Jindal Journal of Business Research, 3, 93-120. https://doi.org/10.1177/2278682116629537 